$\star$ —論文

\title{
課金方式のバリエーション
}

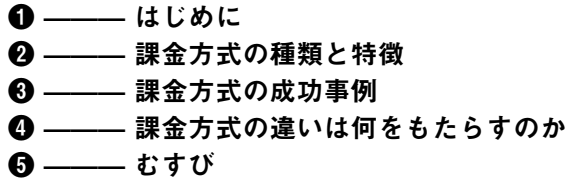

\section{守口 剛}

早稲田大学 商学学術院 教授

\section{(1) はじめに}

プライシングにはいくつかの側面がある。1 つは，いくらで売るのかを決定すること，つま り価格水準を決めることだ。メーカーが新製品 の出荷価格や希望小売価格を設定したり，小売 業者が扱い商品の店頭販売価格を設定すること がこれに当たる。通常は，プライシングという 用語の意味を上記のように認識することが多い のではないかと思われる。

プライシングのもう一つの重要な側面は, 課 金方式を決めること，つまり，顧客の支払い金 額の積算根拠を定めることだ。最も多く用いら れている方法は, 商品を 1 買うといくら, サー ビスを 1 回利用すると何円というょうに，1回 の購入・利用ごとに支払い金額が積算される ものだ。このような方法は，個別課金制（per product pricing) などと呼ばれる。この他に定 額課金制（flat rate pricing）と呼ばれる方法 もある。この方法の場合, 例えば月額の利用料 金が決まっており，その期間内に何回利用して も月額利用料は変わらない。

このように，課金方式の決定は，何をベース
として製品やサービスの料金を積算するのかを 定めることを意味している。個別課金制の場合 には，1個，1回という購入や利用の個数や回 数が単位となり料金が積算される。定額課金制 の場合には，1ヶ月，1年というように期間を 単位として料金が算出される。

価格水準の決定という意味でのプライシング の重要性は,さまざまな視点で論じられている。 例えば, Marn and Rosiell（1992）は，米国の 2,463社のデータを利用して感度分析を行った 結果を示している。それによると，他の要因は 変化しないと仮定すると, 価格を $1 \%$ あげるこ とによって営業利益は $12.3 \%$ 向上する。同様に, 販売量を $1 \%$ 増加したときの営業利益の向上効 果は $3.3 \%$ であり, 変動費, 固定費を $1 \%$ 削減し たときの効果は，それぞれ $7.8 \%, 2.3 \%$ となっ ている。

このように, Marnらは, 価格, 販売量, 変 動費, 固定費の 4 つの変数の中で, 利益に対す る最も大きなインパクトを有しているのが価格 であることを明らかにした。さらに彼らは，利 益に対するインパクトを価格と販売量で比較す ると, 通常は前者が後者の $3 \sim 4$ 倍の大きさに なるとしている。これと同様の分析が, Dolan 
and Simon (1997), 青木 (2003), Raju and Zhang（2010）などで行なわれているが，価格 が最も大きなインパクトを持ち，販売量のそれ の $3 \sim 4$ 倍に達するという特徴は, どの研究で も同じように示されている。

価格水準の決定の重要性は, 上記のような利 益に対する効果という側面から論じられている だけではなく, 売上やシェア, 消費者の購買行 動や心理への影響，ブランドのイメージやロイ ヤルティに対するインパクトなど，広範な角度 から議論されてきた。その一方で，課金方式の 重要性, 企業の業績や消費者行動に対するイン パクトなどについては, ごく少数の研究が焦点 を当ててきたにすぎない。

ところが，近年では，携带電話業界に代表さ れるように，さまざまな課金方式が複雑に組み 合わされて運用されるような例が増加してき た。また，コンタクトレンズ業界に定額課金制 を取り入れたメルスプランや，アルバイト情報 サイトにおいて成果ベースの課金を行なうジョ ブセンスのように，競合他社とは異なる課金方 式を採用することで大きな成功をとげる事例も 増加しているように見受けられる。

上記のことを勘案し, 本稿では, 課金方式に 焦点をあてその種類と特徴を概観した上で, 競 合他社とは異なる課金方式を採用している企業
の事例を考察する。これらを通じて, 課金方式 の相違が企業の業績や消費者の行動にどのよう なインパクトを与えるのかについて整理を行な うことが，本稿の目的である。

\section{2 — 課金方式の種類と特徵}

ここでは, 課金方式の種類について, 守口・ 八島 (2007), Raju and Zhang (2010), 守口 （2012）などを参考として整理を行なう。とり 上げる主な課金方式は表ー 1 に示される。一般 的に採用されている, 個別課金制, 定額課金制, 従量課金制 (usage-based pricing) の他, 成果 ベース課金制 (outcome-based pricing), 申告 ベース課金制 (pay as you wish pricing), そ して上記の中の複数の方式を併用する併用型課 金制（hybrid pricing）について，順をおって 説明しよう。

\section{1. 個別課金制}

先述したように，最も一般的に採用されてい る課金方式は, 1 個の商品, 1 回のサービスを 購入・利用するごとに料金を積算する方法であ る。このような方式は, 個別課金制あるいは都 度課金制と呼ばれる。

消費者が店舗や自動販売機で商品を購入する

表——1

主な課金方式の種類と特徵

\begin{tabular}{|l|l|}
\hline \multicolumn{1}{|c|}{ 課金方式の種類 } & \multicolumn{1}{c|}{ 特徵 } \\
\hline 個別課金制 & 1個の商品, 1回のサービスを購入·利用するごとに料金を積算する \\
\hline 定額課金制 & 一定期間内の利用に関して定額を課金する \\
\hline 従量課金制 & 期間内の利用時間や利用量に応してて料金を積算する \\
\hline 成果ベース課金制 & 顧客側が得た成果に基づいてて料金を積算する \\
\hline 申告ベース課金制 & 顧客が支払いたい額に基づいてて料金を決定する \\
\hline 併用型課金制 & 上記の複数の方式の併用で料金を積算する \\
\hline
\end{tabular}




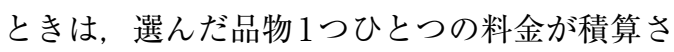
れ，支払いを行なう。これは，個別課金の代表 的な例である。また，切符を買って電車を利用 したり, チケットを買ってコンサートやスポー ツの試合を観るようなケースも, 該当するサー ビスを 1 回利用する度に料金が積算されるもの であり，個別課金制に該当する。

ケーブルテレビのペイ・パー・ビューやイン ターネット業界に扔けるコンテンツ課金は, 利 用者がコンテンツを観たり，ダウンロードする たびに料金が発生する。この方法も個別課金制 に位置づけられる。また，オンラインゲームの 世界には，ユーザーがゲーム上で利用するため の武器や衣服などのアイテムを購入するごとに 料金が発生する，アイテム課金と呼ばれる課金 方式がある。この方法も，個別課金制の一形態 であると理解できる。

\section{2. 定額課金制}

個別課金制に次いで一般的に採用されている 方法は，定額課金制だろう。この方法は，一定 期間内の利用の対価として定められた金額を支 払えば，期間内は何回でも利用ができるという ものだ。交通機関の定期，月額制のスポーツク ラブなどが定額制の代表的な例である。

インターネット・プロバイダーは, 以前は利 用時間に応じて課金する従量課金制を採用して いる企業が多かったが，近年では多くの企業が 定額課金制を採用している。この場合, ユーザー は月額の固定料金を支払えば，時間を気にせず にインターネットを利用することができる。逆 に言えば，利用時間が少ない場合でも，固定の 料金を支払う必要がある。

定額課金制は，個別課金制を採用している競
合企業に対する価格競争手段として利用される ことがある。音楽配信サービスでは現在，アッ プルが運営するiTunesが業界リーダーであり， 圧倒的なシェアを持っている。iTunesを利用 するユーザーは，好きな楽曲を1曲単位（また はアルバム単位) でダウンロードすることがで きる。曲によって価格は異なるが, 日本市場の 場合には 1 曲当たり 150 円から 200 円程度の価 格が多い。このように, iTunesは個別課金制 を採用している。

音楽配信サービスの業界でアップルに大きく シェアで遅れをとっているソニーは, 2012 年 7 月3日から，定額課金制の “Music Unlimited” というサービスを開始した。このサービスを利 用するユーザーは，30日間で 1480 円という定 額のサービス料を支払うと，1000万曲の中か ら好きな曲を, PCやスマートフォン, 携带音 楽プレーヤーなどを通じていつでも聴くこと が可能となる。iTunesの個別課金と比較する と，月間で 10 以上の楽曲を楽しむユーザーは， Music Unlimitedeの1480円という定額課金の 方が得をする計算になる。このことは, 特にへ ビーユーザーにとって, 価格面での大きな魅力 になると考えられる。

上記のような例とはやや性格の異なる定額制 の例として, 飲食店の食べ放題, 飲み放題があ げられる。飲食店の一般的な課金方式は個別課 金だ。それぞれのメニューごとに価格が決まっ ており，注文に応じて料金が積算される。これ に対して, 食べ放題, 飲み放題の場合, 通常 は 2 時間とか 3 時間という制限時間が設定され， 定額を支払うことによって時間内であれば追加 料金なしで対象のメニューを食べたり，飲んだ りできる。 
一般的な定額課金制では, 月や年といった比 較的長い期間を単位とすることが多いが，食べ 放題，飲み放題の場合には 2 時間， 3 時間とい うような短い時間を単位としている。しかし, 一定の期間（時間）を積算根拠として料金が決 められるという点で, 基本的な考え方は, 他の 定額課金制と同じである。

\section{3. 従量課金制}

従量課金制は, 顧客の利用時間や利用量に応 じて課金する方式だ。電話料金の積算方式には 多くの種類があるが, 月間の通話時間の長さに 応じてその月の利用料を積算する方式がコアに なっている場合が多い。これは，従量課金制の 代表的な例である。

時間貸しの駐車場の方式も, 利用時間に応じ て料金を積算する従量課金の一形態に位置づけ られる。駐車場の場合には, 1日の利用料金に 上限が設けられている場合がある。例えば， 1 時間当たりの利用料金が 200 円で，1日の上限 価格が 2400 円というようなケースがこれに当 たる。このような方式は, 従量課金上限制, 従 量課金キャップ制などと呼ばれる。

アミューズメント施設には, 従量課金制を採 用しているところが多く見られる。例えば，イ ンターネットカフェや漫画契茶では, 顧客の利 用時間に応じて料金を積算する方法が，基本的 な課金方式として採用されている場合が多い。

上記はいずれも，利用時間による従量課金の 例であるが，利用量に応じて課金する方式も従 量課金制に含まれる。例えば，携帯電話の料金 を, 顧客が利用したパケット量 ${ }^{1)} に$ 応じて積算 する方法は, 利用量に応じた従量課金制の一つ である。
近年では, クラウド型のITサービスを提供 している企業が従量課金制を採用する例が多く みられる。この場合は, 顧客のITリソースの 利用量や利用時間に応じて, 利用料金を積算す ることになる。

\section{4. 成果ベース課金制}

成果ベース課金制は，製品やサービスが顧客 にもたらしたメリットや成果に基づいて料金を 定める方式だ。この方法を採用している代表的 な例として，インターネット広告におけるク リック課金があげられる。インターネットのバ ナー広告やリスティング広告では, 広告が何回 掲載されたのかという露出べースではなく，実 際にユーザーに何回クリックされたのかを基準 として金額を積算する方法が一般的に採用され ている。

広告のクリックではなく, その先の購入を ベースとして広告料を積算する方法もある。こ の方法はコンバージョン課金と呼ばれている。 クリック課金もコンバージョン課金も, 広告の 成果をベースとして料金を積算する方法であ り，成果ベース課金制の一つに位置づけること ができる。

ジョブセンスというアルバイト情報サイトが ある。アルバイトを採用したい企業がこのサイ 卜に募集広告を出し，アルバイトをしたいと考 えている人がそれを見て応募する。その面では 一般的なアルバイト情報サイトや情報誌と同一 だが，このサイトは成果ベース課金制で運営さ れている。

企業がアルバイトの募集広告をこのサイトに 揭載しても，その時点では料金は発生しない。 広告をみて応募してきた人をその企業が実際に 
採用した時点で, 料金が発生する仕組みになっ ている。アルバイトの募集広告を出す企業に とっては，実際に人を採用することが広告の成 果であり，そのことをべースとして料金が積算 されているのである。

上記はいずれも, 無形のサービスの領域に おいて成果ベース課金制を採用した例である が，有形の製品をべースにした成果ベース課金 の例もある。日立製作所は, HDRIVEという ソリューション・ビジネスを展開している（恩 蔵, 2005)。これは, インバーターとモーターを, 日立が顧客の工場に無償で設置し, 毎月の省工 ネ効果の一部をサービス使用料として徴収する というものだ。ここでは, 顧客側の省エネとい う成果をベースとして，毎月の料金が積算され る。

顧客は, 自社工場にエネルギー効率の良い最 新式の機器を導入すれば省エネを実現すること ができるが，そうした機器の導入には多額の投 資が必要となる。そのため, 多くの顧客は効率 が悪い旧式の機器を利用し続けることになると いう。HDRIVEを利用することによって，顧 客はイニシャルコストなしで新しい設備を導入 することが可能となり，省エネルギーと経費削 減を実現することができる。

通常のビジネスであれば, 日立製作所がイン バーターとモーターという製品を顧客に販売す る。この場合，顧客は個別課金によって積算さ れた料金を支払うことになる。一方でHDRIVE の場合には，顧客は日立が提供するサービスを 利用して，成果ベースで積算された料金を支払 う。上記の説明に表れているように, HDRIVE では, 製品の販売ではなくサービスの提供へと ビジネスモデルが変化し，個別課金から成果
ベース課金へと課金方式が変わっている。この ケースでは, ビジネスのサービス化と課金方式 の変化とが密接に結びついている。この点につ いては, (4)で再度検討する。

上記のように，成果ベース課金制を採用して いるのは, B to B領域の企業に限られているよ うに見受けられる。顧客が企業である場合には， 広告のクリック数や人材の採用者数などのよう に，ビジネス上で重要となる客観的な指標で成 果を測定することが可能な場合が多い。

これに対して消費財の領域では, 通常は成果 を客観的に測定することが難しい。飲み物を飲 んで美味しかったとか, 小説を読んで面白かっ たという消費者にとっての価值を，客観的に指 標化することは普通は困難だろう。消費財の中 にも, ダイエット関連商品のように, 体重や体 型の変化という成果を客観的な数值で捉えるこ とができるものもある。しかし，この場合も， 体重や体型の変化にはさまざまな要因が影響し ているはずであり，商品による効果だけを識別 することは難しいはずだ。

次に説明する申告ベース課金制は，顧客自己 申告によって価格を設定する方式であり，消費 財において成果ベース課金を実施する方法だと 位置づけることもできる。

\section{5. 申告ベース課金制}

ごく一部の企業が採用している特殊な課金方 式の一つに，申告ベース課金制がある2)。この 方法は, 製品やサービスを販売する企業側では なく，顧客側が支払い金額を決定するという方 式である。

イギリスのロック・バンドのレディオヘッド が 2007 年に「イン・レインボウズ」というア 
ルバムを発表した際に，この申告ベース課金制 を採用した（Raju and Zhang, 2010）。このア ルバムをネットでダウンロードするファンは, 支払い金額を自分で決めて実際にその金額を支 払う。無料でアルバムをダウンロードすること も可能である。

この結果，20日間で 180 万人以上がこのアル バムをダウンロードし，そのうち $40 \%$ がお金を 支払った（60\%が無料でダウンドードした）。e コマース調查会社のコムスコアによると，この アルバムをダウンロードした顧客は平均で 2.26 ドルの支払いを行い, 通常の価格設定による販 売よりも，おそらく多額の利益をもたらしたと いう。

申告ベース課金を採用しているその他の例と して, Raju and Zhang (2010) はコーヒーショッ プやレストランの事例をあげている。これらの 店を利用した顧客は，コーヒーや食事を楽しん だ後に，顧客自身がふさわしいと思う料金を支 払うことになる。彼らはさらに，以前からこの 方式を採用している業種の例として，ストリー トパフォーマーをあげている。ストリートパ フォーマーの場合にも，パフォーマンスを楽し んだ顧客が，自分の評価に応じた金額を支払う ことになる。

このように，申告ベース課金は，顧客側が自 分の評価や満足度を基にして料金を設定する方 式である。その意味でこの方法は, 顧客の主観 的な評価に基づいた成果べース課金だと捉える こともできる。先述したように, B to Cの領域 では，顧客側にもたらされた成果を客観的に測 定することが難しいために，成果ベース課金が 成り立ちにくい。しかし，顧客にとっての成果 を，顧客の主観的な評価や満足度であると捉え
れば，申告ベース課金を成果ベース課金の一種 だと位置づけることもできる。

いずれにしても，申告ベース課金は採用する 企業側にとって，価格を非常に低く設定されて しまうリスクが伴う。Raju and Zhang (2010) は, この方式が成功する要件として，「限界費 用が低いこと」「買い手と売り手の間に強いつ ながりがあること」など五つをあげている。

\section{6. 併用型課金制}

上述してきた複数の方式の組み合わせによっ て課金を行なう方法もある。例えば, 固定電話 の料金や, ガス, 電気などの公共料金は, 月額 の固定料金と従量課金が併用されている。こ のような課金方式は, 二部料金制（two part pricing）と呼ばれる。固定電話, 電気, ガス などを一つの世帯に供給することによってかか る固定費の部分を定額課金で回収し，各世帯の 使用量に応じて発生する変動費の部分を従量課 金によって回収するというのが，二部料金制の 基本的な考え方である。

この二部料金制を, 電話やガスなどとはまっ たく異なる領域に応用している例として，コス トコなどの会員制小売業をあげることができ る。会員制小売業の顧客は, 通常は定額の年会 費を支払うことで会員となり，店舗を利用して 買物をするときには，買った商品に応じた個別 課金で支払いをする。この方式は，年会費とい う定額課金と，買った商品の分に応じた個別課 金を組み合わせているのだと理解できる。

固定電話や電気料金などと異なり，会員制小 売業の場合には, 会員が 1 人増えても設備など の固定費が発生するわけではない。したがっ て，上述した二部料金制とは基本的な考え方が 
異なるが, 定額部分と変動部分に分けて料金を 設定するということについては，同様の仕組み になっている。会員制小売業の課金の仕組みに ついては, 後で詳しく考察する。

上述した固定電話が，定額課金と従量課金の 組み合わせという，併用型課金の中ではシンプ ルな方式をとっているのに対し，携帯電話やス マートフォンの課金方式は非常に複雑だ。ス マートフォンの課金方式を例にとると，通信料 金については，月額の定額部分と通信量に応じ て変わる従量制とが併用されている場合が多 い。さらに，有料のアプリをダウンロードする 際には，個別課金によって支払い金額が積算さ れる。このケースでは, 上記の方式のうち, 個 別課金，従量課金，定額課金が併用されている ことになる。

\section{(3 — 課金方式の成功事例}

ここでは，競合企業とは異なる課金方式を採 用し，成功している事例を検討しよう。1つ目 の事例は, コンタクトレンズ・メーカーのメニ コンが運営しているメルスプランというサービ スである。コンタクトレンズは，他の製品と同 様に, 通常は個別課金によって販売されている。 一方でメルスプランでは，定額課金制が採用さ れている。2つ目の事例は, 会員制小売業のコ ストコである。先述したように，コストコの場 合には，年会費という定額課金と，顧客が店舗 で買った商品に応じて支払う個別課金との併用 型課金制を採用している。

\section{1. メルスプランの定額課金制 ${ }^{3)}$}

メルスプランは, コンタクト・レンズ・メー
カーのメニコンが展開している，会員制のサー ビスである。会員は毎月定額の会費を支払うこ とにより，1年に 1 回新しいコンタクトレンズ が提供される他，レンズが污れたり破損した場 合には，無料で新しいレンズと交換できる。

コンタクトレンズを利用したい顧客は，通常 は両眼 1 組分の価格を支払って購入する。これ に対してメルスプランでは, 毎月定額の料金を 支払うことで上述のようなサービスを受けるこ とができる。

会員はまず，入会時に入会金と 2 カ月分の会 費を支払うことで，2枚のレンズが提供される。 入会金と月額費用はレンズのタイプによって異 なる。メニコンの主力商品であるハードコンタ クトレンズ ${ }^{4)}$ の一般的なタイプの場合，月額費 用が 1,890 円，入会金が 5,250 円となっている。

メルスプランの月額費用を 1,890 円（一般的 なハードコンタクトの場合）に設定する過程で は，直営店においてテストマーケティングが実 施された。その際に，月額費用が2,000円を超 えると消費者の受容性が低くなることが実証さ れ，上記の会費が設定された。この価格は，消 費者にとって従来のハードコンタクトの購入費 用との比較で割高感が発生しにくい価格である とともに，使い捨てレンズに比して大きな割安 感を得ることができる価格であったと解釈でき るだろう。

月額費用は製品の購入費用の分割ではなく, 継続的役務提供に関する費用，つまりサービス の提供費用と位置づけられている。メーカーで あるメニコンが，製品を販売する代金としてで はなく，サービス提供の対価として消費者から 月額費用を受け取っている。このことは，毎月 の定額課金という課金制度と密接に関連してい 
る。

メルスプランは2001年に導入された。1990 年から 2006年までの売上推移は図ー 1 に示され ている。この図から分かるように，1995年ま では順調に売上が拡大し続けているが，ちょう どこの時期から使い捨てコンタクトレンズの成 長がはじまり，それとともにハードコンタクト レンズを主力としてきたメニコンの売上が落ち 込んでいく。ところが，2001年にメルスプラ ンが導入されると, 翌年から売上が $V$ 字型に回 復している。

このように, 使い捨てコンタクトレンズの成 長による逆風の影響と，それをメルスプランの 導入によって乗り切っている様子が, メニコン の業績推移に明確に表れている。

メルスプランの定額課金制が奏功した要因に は，いくつかのことをあげることができる。こ こでは, 主要なポイントを一つだけあげよう。

定額課金制の大きな効果の1つは, 顧客継続 率の向上である。メルスプランの会員脱落率は 年間 $7 \%$ 程度だという。先述したように，ハー
ドコンタクトレンズの平均的な購入間隔は 2 3 年程度だとされる。メルスプランの場合, 上 記数值から例えば 3 年後の顧客継続率を算出す ると約 $80 \%$ となる。通常の販売方法のもとで 新規で購入する場合の一般的なリピート率は分 からないが，おそらくこれよりもかなり低い数 值となるだろう。

個別課金制で製品を購入する場合には，消費 者は買い替えの度に製品選択の意思決定に直面 する。特に，新しい機能を持った新製品が頻繁 に出たり，価格競争が激しい製品分野では，消 費者が買い替えの度に多くの選択肢を比較検討 する可能性が高くなるだろう。その結果として ブランド・スイッチが発生する確率も高くなる と思われる。

一方で，定額課金制の場合には，明確な意思 決定ポイントが発生しにくいため, 一度利用し はじめた顧客が他の製品に乗り換える可能性は その分低くなると考えられる。また，メルスプ ランの場合, 会員はレンズが異なる他のプラン に乗り換えることができる。レンズを購入する

口图-1

\section{メニコンの年間売上高の推移}

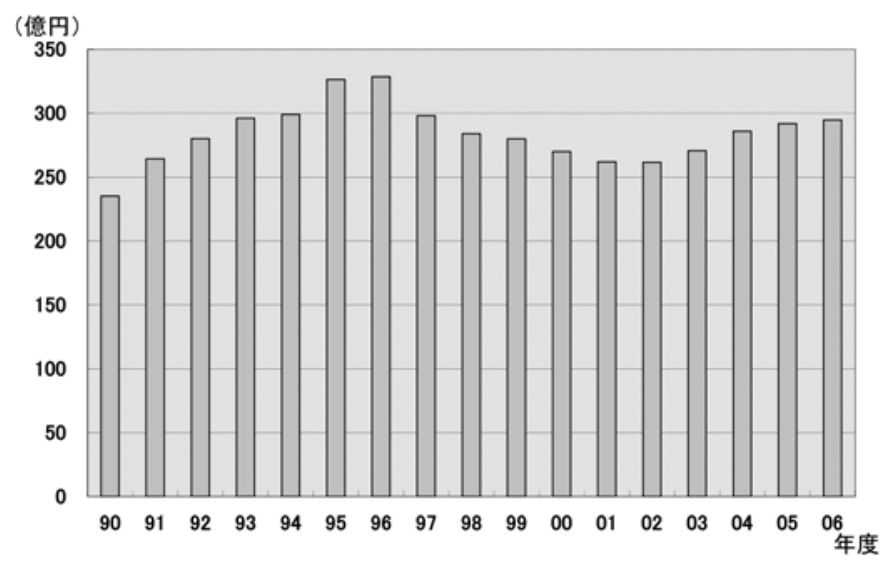


場合には, 現在使用しているレンズの寿命や破 損などの夕イミングを待って, 新しいレンズに 乗り換えるのが普通だろう。メルスプランの場 合には，そうしたタイミングを気にせずに別の 製品に乗り換えることができる。このように, 自社内でのスイッチが円滑に行いやすいという ことも，他社へのスイッチを防止することにつ ながっていると考えられる。

\section{2. コストコの併用型課金制 ${ }^{5)}$}

コストコは, 1983年にアメリカで創業された。 正式には, メンバーシップ・ホールセール・ク ラブと呼ばれる業態であり，年会費を支払って 会員となった法人と個人が利用することができ る。法人顧客としては, 中小の食品小売業や飲 食店などが多いと考えられる。ホールセールは 卸売業を意味しているが, これは上述のように 法人顧客をも対象としているためである。ただ し, 法人顧客に対して配送をしているわけでは なく，個人顧客と同じょうに法人顧客も店舗で 買い物をする。したがって，コストコは実質的 には, 法人顧客と個人顧客の双方を顧客とする 会員制の倉庫型小売業と理解しても差し支えな いだろう。

コストコの年会費は, 日本では個人会員が 4,200円，法人会員が3675円である。米国では, 通常会員が個人・法人ともに50ドル, エグゼ クティブ会員が個人・法人ともに 100 ドルとなっ ている。コストコを利用する顧客は, 上記の年 会費を支払った上で店舗で買物をし，その料金 を買物のたびにレジで支払うことになる。この ように，コストコの課金方式は年会費という定 額課金と，購入した商品の個別課金という2つ の併用型であると位置づけられる。
先述したように, この併用型課金は, 利用し た分に応じた課金と定額課金との併用という意 味で，公共料金などの 2 部料金制の応用である と捉えることもできる。ただし，コストコをは じめとする会員制小売業の場合は, 会員の獲得 と維持に大きな設備投資やコストがかかってい るわけではないので, 固定電話やガスなどのよ うに定額分で設備設置分の固定費を回収すると いうものとは発想が異なる。コストコの場合に は，定額の会費収入を大きな利益源とすること によって，個別課金による商品販売における圧 倒的な低価格を実現するという仕組みになって いる。

コストコの店舗数は全世界では592店であり， その大半は北米に立地している。日本では 13 店舗が営業しており，アジアでは日本の他に台 湾と韓国にも進出している。会員数は個人と法 人を合わせて全世界で 6,400 万人に達する。日 本での会員数は, 日本での会員数は公表されて いないが，200万人を超えると言われている ${ }^{6}$

コストコの日本法人の業績は公表されていな いので, ここでは米国本社の年次報告書をもと にして, グローバルの業績を確認しょう。売 上高は図ー2のように推移している。リーマン ショックの影響で 09年の売上はその前年を若 干下回っているが，それ以外の年は右肩上がり で伸張していることが分かる。

粗利益率と営業利益率は図ー3のように推移 している。驚くのは粗利益率の低さだ。一般的 な小売業者の場合, 少なくとも $20 \sim 30 \%$ の粗 利益率がある。例えば, 同じディスカウント 業態のウォルマートの粗利益率は $24.7 \%$ であり (2011年), 日本の代表的なスーパーの粗利益 率はほぼ $20 \%$ 台後半になっている。図ー3のよ 
図-2

コストコの売上高推移

（億ドル）

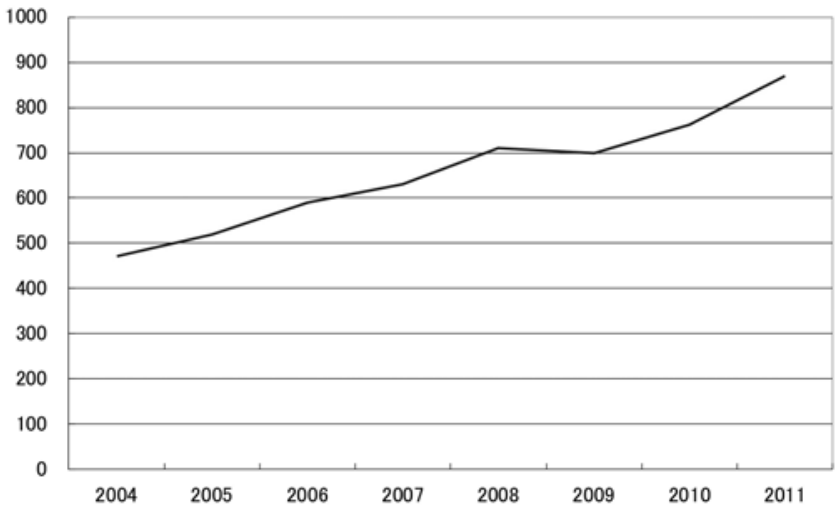

(年)

図—3

粗利益率 (上の線) と営業利益率 (下の線) の推移

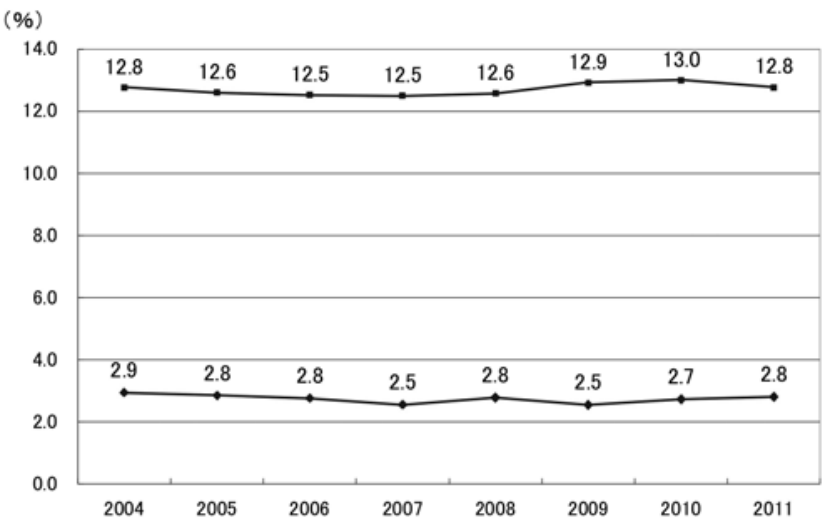

(年)

うにコストコの粗利益率は $10 \%$ 強で推移して おり，他の小売企業に比してその数值が極端に 低いことが理解できる。この数值は, コストコ が利幅を抑えて低価格で商品を販売しているこ とを如実に表している。

一方, 営業利益率の值は $3 \%$ 弱となっている。 数值そのものはそれほど高い水準ではないが, 年による振れ幅が非常に小さく安定して推移し
ていることは特筆できる。図ー4は営業利益額 と会費収入額の推移だ。両者ともの順調に伸び ていることが分かる。また，営業利益額と会費 収入額が近接していることも大きな特徴だ。コ ストコの利益は, 商品販売と会費の両者から得 られる。それぞれにかかるコストは明確には分 からないため, 会費収入の利益貢献度を正確に 求めることは難しい。 
$\star$ ——論文

园—-4

営業利益額（上の線）と会費収入（下の線）の推移

（億ドル）

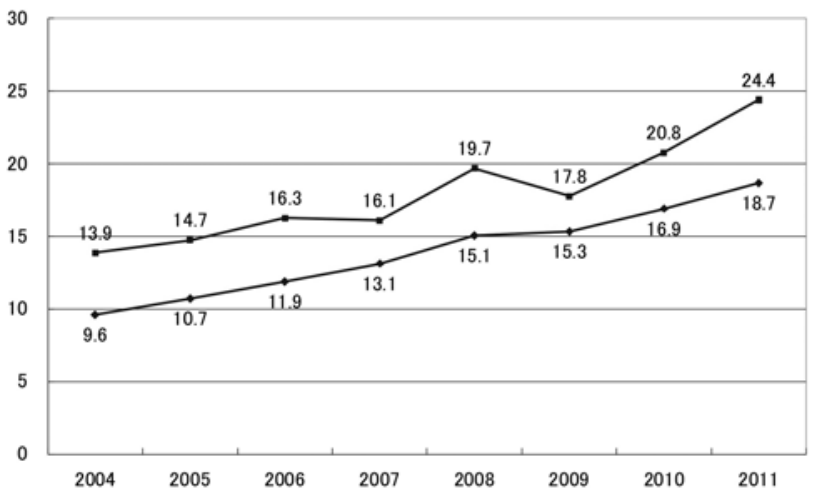

(年)

しかし，商品販売に関連するコストには，仕 入れ, 配送, 店舗運営などのさまざまなコスト がかかるのに対して，会費収入に関連するコス トは, カード発行や会員管理など相対的にみれ ばごく僅かな費用しか発生しないと考えられ る。そこで, 仮に営業利益に占める会費収入 の比率を算出すると，11年が $76.5 \%, 10$ 年が $81.4 \% ， 09$ 年が $86.3 \%$ というように，ここ数年 は $80 \%$ 前後で推移している。

上述したように，商品販売と会費収入それぞ れの利益貢献度は正確には分からないが, これ まで述べてきたことから判断すると，コストコ の利益のうちのかなりの割合が会費収入によっ てもたらされて言っても間違いはないだろう。

\section{(4) 課金方式の違いは何をもたら すのか}

ここでは, 課金方式の変化が, 企業の業績や 消費者行動に対してどのようなインパクトをも
たらすのかについて検討する。そのインパクト は多岐に渡ると考えられるが，ここでは，(2)と (3)でとりあげた事例と関連付けながら，4つの 視点で整理を行なう。

\section{1. モノからサービスへの転換}

有形のモノを販売する場合には，通常は個別 課金制が用いられる。モノの場合には，1個い くら（場合によっては 2 個や 3 個でいくら）と いうように料金を積算することが最も自然な方 法であることはすぐに理解できるだろう。定額 課金や従量課金などの，それ以外の方法を採用 している事例のほとんどは無形のサービスであ る。

モノの場合には, 一定の原材料コストが発生 するために，限界費用が相対的に高くなる。こ のため，期間内であればいくら利用しても金額 は一定という定額制や，使った分に応じて後で 料金を徴収するという従量制を適用することが 難しい。 
このことを逆に考えると, 有形の商品を販売 するための一般的な方法である個別課金制を他 の方法に変えることによって, 扱っている商品 の性質がモノからサービスへと変化する可能性 があると捉えることもできる。

例えば, メルスプランのケースを振り返って みよう。先述したように，メルスプランの月額 費用は，製品の購入代金ではなく，サービス提 供費用だと位置づけられている。メルスプラン の場合, 毎月の定額の中で污れや破損による交 換は何回でも可能であるが, 実際にはそれほど 頻繁な交換は発生しない。したがって，メルス プランの場合には, 月額費用によって交換保証 というサービスを提供しているという意味合い が強い。

一方で, 通常の個別課金でコンタクトレンズ を販売し, 価格を少し高めにすることで交換保 証を付加するという方法も考えられる。この場 合は, 提供するのはあくまでコンタクトレンズ という製品であり，交換保証というサービスは 付加的な位置づけになるだろう。ところが, メ ルスプランの場合には, 交換保証の提供に定額 制という課金方法が組み合わせさることによっ て, 仕組み全体がサービス提供と位置づけられ ることになった。つまり，メルスプランの事例 では，定額制という課金方法をとることによっ て, サービスとしての性質が明確化されたのだ と理解することができる。

日立製作所のHDRIVEも, 課金方式が変化と, モノからサービスへの変化とが結びついている 事例である。HDRIVEの場合には，顧客はイ ンバーターとモーターという製品への対価を支 払うのではなく，それを利用することで得られ る効果に対して, 成果ベースで積算された料金
を支払っている。

レビットにならって言えば7),「顧客は最新 式のインバーターやモーターというモノが欲し いのではなく，それらを利用することで得ら れる成果を欲している」はずだ。HDRIVEは, 料金の積算根拠をモノそのものからモノを通じ て得られる成果に変えることによって, 提供物 の性質についても有形のモノから無形のサービ スへと変化させたのだと解釈することができ る。

個別課金制から他の方式への変化は, 料金の 積算単位が, 1個, 2個というモノの単位から 他の単位に変わることを意味している。した がって, 有形のモノの課金方式を個別課金から 他の方式に変えることは, 販売対象の性質をモ ノからサービスへと変えることを促しているの だと理解することができるだろう。

\section{2. 収益の安定化}

課金方式が異なると, 顧客の意思決定の頻度 も変わることになる。個別課金制の場合には, 製品やサービスを購入・利用するごとに料金が 新たに発生する。このため, 利用するか否かの 意思決定も頻繁に発生することになり, 必然的 にブランド・スイッチを検討する機会も多くな ると考えられる。

これに対して, 定額課金や従量課金の場合に は，利用するたびに大きな意思決定が必要にな る分けではない。これらの課金方式をとるサー ビスを最初に利用し始める際には, 複数のサー ビス間での比較検討があるはずだ。ところが, 一度利用しはじめてしまえば，更新や乗換えを 検討する機会は,それほど頻繁には発生しない だろう。 
先述した, メルスプランの顧客継続率の高さ も，定額制という課金方式と密接に関連してい る。そして, 顧客数があまり変動せずに定額の 収入が毎月発生することは，メニコンの収益の 安定性に非常に大きく寄与していると考えれら れる。

コストコのケースでも, 課金方式と収益の安 定性との関係をみてとることができる。先述し たように，図ー4はコストコの営業利益額と会 費収入の推移を示している。ここから，営業利 益額の推移に比して, 会費収入が安定的に推移 していることが分かる。商品の販売は景気や天 気などの要因によって左右されるが，年会費を 支払っている会員数は，それよりも安定的に推 移するはずだ。例えば,リーマンショックがあっ た09年には，営業利益は前年に比して落ち込 んでいるが，会費収入は微増している。このこ とは, 景気変動などの影響を受けやすい商品販 売収益の下支えをする役割を，会費収入が果た していることを意味している。

\section{3. 消費行動の変化}

課金方式の違いは，消費行動にも影響を与え る。例えば，インターネット・プロバイダーの 課金方式が従量制から定額制に変わったこと は，ユーザーのインターネット利用方法を大き く変化させた。同様に, 携帯電話のパケット定 額制の導入は, 携帯電話からのメールやイン ターネットの利用動向に大きな影響を及ぼし た。

メルスプランの事例からも, 課金の仕組みが 消費行動を大きく変える力を持っていることが 理解できる。メニコンの田中英成社長によると， 「従来のようにコンタクトレンズを購入する方
法だと, 多少污れたり, 不具合の生じたコンタ クトレンズでも使い続けてしまう場合が多い」 と言う ${ }^{8)}$ 。コンタクトレンズを通常の方法で購 入する場合，消費者の側にそうした意識が働き やすいことは容易に想像がつく。これに対し， 定額制のメルスプランの場合には, 污れや破損 の生じたレンズは無料で交換できるため, 不具 合の生じたレンズを無理に使い続けるケースは 大きく減少するはずだ。このように，課金の仕 組みによって消費者に正しい使い方を促すとい うことが，メルスプランにおける定額制の大き な意義の一つとなっている。

Gourvill and soman（2002）は課金の方法や 支払いの夕イミングによって，さまざまな領域 における消費者の行動が変化することを論じて いる。さらに, 上田（2006）は課金方法による 顧客関係強化について考察している。

\section{4. 価格競争の土俵を変える}

課金方式を変えることは，価格競争の土俵を 変えることを意味している。このことは，価格 競争に打ち勝つための手段にもなりえるし，価 格競争を回避するための手法としても利用でき る。

コストコの事例では, 定額の会費収入の存在 が，圧倒的な低価格での商品販売を可能として いる。一度年会費を支払った顧客にとって会費 はサンクコストであり, 商品の販売価格が店舗 選択時の大きな評価ポイントになるはずだ。こ こでは，上記のような仕組みで商品の低価格販 売を可能としているコストコは，大きな価格競 争力を持つことになる。したがって，コストコ の会員が, 複数チェーンの価格を評価する際に は，コストコだけが非常に有利な立場を占める 
ことになる。課金の仕組みによって，コストコ は他のチェーンとは異なる土俵で価格競争をし ていると解釈することもできるだろう。

先述したように,ソニーの Music Unlimited は，12年 7 月にスタートした定額制の音楽配信 サービスである。30日間で 1,480 円という定額 課金は，特にへビーユーザーにとっては魅力的 な仕組みだろう。同じ業界で圧倒的なシェアを 有するiTunesが，1曲当たり 150円〜200円程 度の個別課金で楽曲を販売しているのに対し て, 価格競争上の優位性を獲得することが, ソ ニーが定額課金制を導入した大きな理由の一つ だと考えられる。

その業界で一般的な課金方式と異なる方法を 採用することが，価格競争を回避することにつ ながる場合もある。メルスプランの事例では, 他企業が個別課金を採用する中で定額制を導入 した。導入した当時は, 店頭レベルでのコンタ クトレンズの価格競争が激化しており，メー カーであるメニコンもその対応に苦慮していた という。ところが，定額制の導入によって，一 般的なコンタクトレンズの販売価格とメルスプ ランの月額とを同じ土俵で比較することの意味 合いが薄くなり，メルスプランの価格が店頭段 階での価格競争に巻き込まれることがなくなっ た。実際に，当初設定された月額費用（一般 的なハードコンタクトレンズの場合で 1,890 円） は 10 年以上経った現在でも変化していない。

\section{5 — むすび}

以上のように, 本稿では, 課金方式の種類と 特徴を概観した上で，競合他社とは異なる課金 方式を採用し，成功している例としてメルスプ
ランとコストコのケースを検討した。最後に, 課金方式の相違がもたらすインパクトについ て，モノからサービスへの転換，収益の安定性， 消費行動の変化，そして価格競争の土俵を変え る, という諸点から考察した。

本稿でもいくつかの例を紹介したように, サービス財では，課金方式を柔軟に変化させた り，組み合わせることが比較的に容易にできる 場合が多い。交通サービスは，昔から 1 回の利 用ごとに課金する方法と，定期を利用した定額 課金との双方を利用してきた。遊園地やカラオ ケボックスなどのアミューズメント施設を例に とると，1回の利用に対する個別課金，利用時 間に応じた従量課金，年間パスポートなどの定 額課金などのさまざまな課金方式が存在してい る。

インターネット上で流通するデジタルコンテ ンツの場合も，さまざまな課金方式を採用する 余地が大きい。一般に，デジタルコンテンツは 限界生産コストが低く，流通コストもほとんど かからない。このような特徵を背景として，デ ジタルコンテンツの場合には, レディオヘッド が採用した申告ベース課金も含めて，さまざ まな課金方式を検討することが可能だと思われ る。

その一方で，一般的な有形商品の場合には， 現状では個別課金制による販売がほとんどを占 めており，他の課金方式を採用する可能性はあ まりないようにも思われる。しかしながら，メ ルスプランやHDRIVEの事例にみられるよう に，それまでは個別課金制によって当たり前の ように販売されていたものに，定額課金や成果 ベース課金が用いられた例も存在する。さらに は，有形の商品を販売するコストコのような小 
$\star$ 論文

売業が，年会費というかたちで定額課金を併用 する事例もみられる。

これらの事例を勘案すると，有形の商品につ いても，課金方式を柔軟に変化させる余地はあ るのではないかと思われる。例えば，昔から存 在する商いの方法の一つに，「富山の置き薬方 式」というものがある。薬の販売業者がいろい ろな薬が梱包された箱を家庭や職場に置き, 半 年か 1 年後の再訪し，その間に使用された分の 料金を請求するというやり方だ。江戸時代に富 山の薬の行商人が秘伝の丸薬を諸国に売り歩い たのが起源とされるため，このような名前が付 けられている。

この方法は, 薬を使用した時点で実施的に料 金が発生するという意味では個別課金制に位置 づけられるが，利用した分だけを後で請求する という性質を考えると，従量課金制だと捉える こともできる。いずれにしても，この方法は一 般的な販売方法とは異なる課金方式を採用して おり，有形の製品においても課金方式を柔軟に 見直す可能性があることを示唆していると思わ れる。

\section{注}

1）パケットは，ネットワークを介してやりとりされる 通信量の単位。

2）申告ベース課金制については，本号に掲載されてい る奥瀬論文が詳しく論じている。な书奥瀬は,「ペイ・ ワット・ユー・ウォント (Pay What You Want; PWYW)」方式という用語を使用している。

3）このパートは，守口・八島（2007）をもとにしてま とめている。

4） 2007 年当時は，ハードコンタクトレンズがメニコン の主力商品であり，メルスプランにおける中核的商 品であった。現在では, ハードコンタクトレンズの 他，使い捨てタイプ，定期交換型などのさまざまな タイプがメルスプランの対象商品となっているが, 本稿では主としてハードコンタクトレンズを念頭に
おいて議論を行う。

5）このパートは，守口（2012）をもとにしてまとめて いる。

6）読売テレビ「かんさい情報ネットten !」」11 年 4 月 4 日放送による。

7）Levitt（1969）の有名な次の一説「昨年，4 分の 1 インチのドリルが 100 万個売れたが，これは人々が 4 分の1インチのドリルを欲したからではなく, 4 分の 1 インチの穴を欲したからだ」による。

8）田中英成社長へのインタビューによる。

\section{参考文献}

Dolan, R. J. and H. Simon (1997), Power Pricing; How Managing Price Transforms the Bottom Line, The Free Press. (邦訳：吉川尚宏監訳（2002）『価格戦略論』 ダイヤモンド社)

Gourville, J. and D.Soman (2002)," Pricing and the Psychology of Consumption," Harvard Business Review, September 90-96.,（邦訳：「プライシングと 消費者心理」『DIAMOND ハーバードビジネスレ ビュー』2003 年 6 月号)

Levitt (1969), The Marketing Mode, McGraw-Hill.（邦訳 : 土岐坤訳（1971）『マーケティング発想法』ダイヤ モンド社).

Marn, M. V. and R. L. Rosiell (1992), "Managing Price, Gaining Profit," Harvard Business Review, SeptemberOctober, 84-94.

Raju, J. and Z. J. Zhang (2010), Smart Pricing, Wharton School Publishing. (邦訳: 藤井清美訳 (2011)『スマー ト・プライシング：利益を生み出す新価格戦略』 朝日新聞出版)

青木淳（2003）『プライシング：消費者を魅了する「値 ごろ感」の演出』ダイヤモンド社.

上田隆穂（2006）「関係性強化型課金方式（CPP： Customer Relationship Pricing) 〜料金設定のイノベー ション〜」『マーケティング・ジャーナル』第 100 号, 58-65.

恩蔵直人 (2005)「日立製作所『HDRIVE』ビジネス」『マー ケティング・ジャーナル』第 97 号, 96-106.

守口剛・八島明朗 (2007)「逆転の発想によるビジネス モデル」『マーケティング・ジャーナル』第 106 号, 75-89.

守口剛（2012）「会費制の導入によるWin-Win 関係の達 成：コストコの収益モデル」『販促会議』2012 年 5 月号, 116-119. 


\section{守口 剛}

1979 年早稲田大学政治経済学部経済学科卒業後, 筑 波大学大学院経営・政策科学研究科経営システム科 学専攻, 東京工業大学大学院理工学研究科経営工学 専攻博士課程, 修了。博士（工学）。財団法人流通経 済研究所, 立教大学社会学部教授を経て現職。著書に, 『プロモーション効果分析』、『マーケティング・サイ エンス入門』(共著),『価格プロモーション戦略』(共 編著）ほか。 